\title{
EFFECT OF MINERAL AND ORGANIC FERTILIZERS ON YIELD AND QUALITY OF SOME EGYPTIAN AND OMANI WHEAT CULTIVARS
}

\author{
M. F. Seleiman, M. E. Ibrahim, I. H. Darwish and A. N.M. Hardan \\ Department of Crop Sciences, Faculty of Agriculture, Menoufia University, \\ Shibin El-Kom 32514, Egypt
}

Received: Jun. 22, 2021

Accepted: Jun. 30, 2021

\begin{abstract}
Two field experiments were conducted at the Experimental Farm, Faculty of Agriculture, Menoufia University, Shebin El-Kom, Egypt during two successive growing seasons of $2018 / 2019$ and 2019/2020. The aims of the experiments were to investigate the effects of mineral and organic fertilizers $(1.100 \% \mathrm{~N}$ as mineral fertilizer; $50 \% N+50 \%$ compost; $50 \% N+50 \%$ biochar; $50 \% N+50 \%$ biogas; and $50 \% N+50 \%$ poultry manure) as soil amendments on yield and grain quality of some Egyptian (Gemmiza 12 and Sakha 95) and Omani (Missani and Cooley) bread wheat (Triticum aestivum L.) varieties. The treatments were arranged in a spilt-plot design with three replications, where the wheat varieties were occupied in the main plots, while the fertilization treatments were randomly distributed in the sub- plots. The results can be summarized as follows:

- Egyptian wheat varieties had the highest values of yield and its components and carbohydrates, while the Omani wheat varieties had the highest values of plant height, straw yield/ fed and protein percentage.

- Application of organic fertilizers (i.e. $50 \%$ biogas or $50 \%$ poultry manure) in a combination with $50 \%$ mineral $\mathrm{N}$ had positive effects on yield and quality of wheat.

- Significant improvements in grain yield and carbohydrate percentage were obtained from Gemmeiza 12 and Sakha 95 varieties when fertilized with $50 \%$ mineral N+50\% biogas or $50 \%$ mineral $\mathrm{N}+\mathbf{5 0} \%$ poultry manure along with $100 \%$ mineral $\mathrm{N}$, which were found to be the most optimal combined treatments for maximize wheat grain yields and under the environmental conditions of studies regions (i.e. Menoufia Governorate). While, Missani and Cooley varieties fertilized with $\mathbf{5 0} \%$ mineral N + $\mathbf{5 0} \%$ biogas or $50 \%$ mineral $N+50 \%$ poultry manure along with $100 \%$ mineral $N$ produced the highest plants, straw yield/ fed and protein percentage.
\end{abstract}

Key words: Egyptian wheat; Omani wheat; Mineral and organic fertilizers; Yield; Quality.

\section{INTRODUCTION}

Wheat (Triticum aestivum L.) is one of the most importance winter cereal crops worldwide, particularly Egypt and Oman. Worldwide, the harvested area and grain yield production were $\mathbf{2 1 4 . 3}$ million ha (ha $=10000 \mathrm{~m}^{2}$ ) and 734.04 million ton during 2018, respectively (FAOSTAT, 2020). In Egypt, the harvested area and grain yield production during 2018 were 1.36 million ha and $\mathbf{8 . 8 0}$ million ton, respectively (FAOSTAT, 2020). On the other hand, the harvested area and grain yield production in Oman during 2018 were 929 ha and 3975 ton, respectively (FAOSTAT, 2020). The Egyptian and Omani local production of wheat is not sufficient to meet with the excessive demand as a result of the continuous increase in the population.

Many researchers reported that using promising and high yielding cultivars as 
well as the application of organic fertilizers such as biochar, biogas, compost and poultry manure can increase the grain yield of wheat and improve the grain quality. Abubaker et al. (2012) studied the performance of biogas residues and pig slurry as individual application or combined with the mineral fertilizer (35, 70 and $140 \mathrm{~kg} \mathrm{~N} / \mathrm{ha}$ ) on the growth and productivity of wheat in Sweden. The authors reported that the yield obtained from plants fertilized with biogas residues was well comparable with mineral fertilizer, but pig slurry resulted in higher yields than mineral fertilizer and biogas residues. On the other hand, Olmo et al. (2014) studied the biochar effects (control and $40 \mathrm{t} \mathrm{ha}^{-1}$ ) on growth and yield of wheat in Spain. They reported that biochar application resulted in a higher grain yield than that obtained from the control treatment. However, grain quality of wheat was not significantly affected by biochar application.

Ibrahim et al. (2019a) studied the effects of the co-application of biochar $(0$ and $10 \mathrm{t} \mathrm{ha}^{-1}$ ) with different rate of mineral fertilizer on yield of wheat. Under all phosphorus fertilizer rates, higher grain yield was obtained from soil treated with biochar than untreated soil during both seasons. Wheat grain yield in the soil amended with biochar and mineral fertilizer was not significantly increased among the application of $50 \%, 100 \%$ and $150 \%$ mineral fertilizer. This probably due to the enhancement of nutrients availability $(N, P$, and $K$ ) as a result of biochar application itself. Hlisnikovský et al. (2020) evaluated the effects of farmyard manure $\left(40 \mathrm{t} \mathrm{ha}^{-1}\right)$, mineral nitrogen (40 kg N ha ${ }^{-1}$ ) applied without phosphorus and potassium fertilizers, application of NPK as well as their combinations on grain yield and grain quality. Mineral fertilizer application in combined with farmyard manure significantly improved grain yield and grain quality in terms of protein content compared with unfertilized plants.

Ibrahim et al. (2019b) evaluated yield and grain quality of five bread wheat varieties (Gemmeiza 11, Gemmeiza 12, Misr 1, Giza 171 and Sids 13) fertilized with different mineral $(75 \mathrm{~kg} \mathrm{~N} / \mathrm{fed}$ ) and organic fertilizers $(6 \mathrm{t} / \mathrm{fed}, 74 \mathrm{~kg} / \mathrm{fed}$ and $238 \mathrm{~kg} /$ fed for compost, phosphate ore and potassium ore; respectively). They stated that Giza 171 and Gemmeiza 11 varieties surpassed the other varieties in the yield and its components (number of spikes/ $\mathbf{m}^{2}$, number of grains/spike, 1000grain weight, spike weight, grain yield/fed and straw and biological yields/fed) and protein percentage. However, the highest carbohydrates and ash percentages were recorded from Gemmeiza 12 and Sids 13, respectively. Conversely, Misr 1 variety produced the lowest values of most abovementioned traits. Concerning the fertilization, they reported that the combinations of mineral and organic $\mathrm{N}$ (50\% of each) significantly increased yield and its components (number of spikes/ $\mathbf{m}^{2}$, number of grains/ spike, grain yield/ fed and straw and biological yields/fed) and protein percentage followed by $100 \%$ mineral $N /$ fed compared to other fertilization treatments. However, the heaviest 1000grain weight and spike weight as well as the highest carbohydrates percentage were obtained when wheat plants were fertilized with $50 \%$ organic $\mathrm{N}$ + phosphate ore + potassium ore/fed.

Different efforts were carried out to increase the grain yield of wheat by using high yielding cultivars as well as using the optimal agricultural practices, particularly fertilization systems such as mineral and/or organic fertilizers (Seleiman et al. 2010; Ibrahim et al. 2019a, 2019b). Thus, application of different fertilizations, particularly organic fertilizations, can be a promising strategy to improve soil fertility and 
increase crop yield. Mostly, the deepest attention was paid to improve the grain yield and its components of wheat instead of improving the quality of grains, flour, and dough regardless of the importance for these properties to get a good product. Therefore, the current investigation was conducted to investigate the optimal agriculture practices in terms of fertilization systems to get the best characters for flowering, productivity, and grain quality of some Egyptian and Omani high yielding cultivars.

\section{MATERIALS AND METHODS}

\section{Experimental location and materials}

Two field experiments were conducted at the Experimental Farm, Faculty of Agriculture, Menoufia University, Shebin El-Kom, Egypt (Latitude $30^{\circ} 31^{\prime \prime} 42^{\prime \prime} \mathrm{N}$, Longitude $31^{\circ} \quad 04^{\prime} \quad 08^{\prime}$ E) during two successive growing seasons of $2018 / 2019$ and $2019 / 2020$. The aims of the experiments were to investigate the effects of mineral and organic fertilizers as soil amendments on yield and technological properties of some Egyptian and Omani bread wheat (Triticum aestivum L.) varieties. The treatments were arranged in a spilt-plot design with three replications, where the wheat varieties (i.e. four varieties) were occupied in the main plots, while the fertilization treatments (five treatments) were randomly distributed in the subplots.

The investigated treatments in the experiments were as follow:
A) Varieties:
1- Gemmiza 12 (Egyptian variety)
2- Sakha 95 (Egyptian variety)
3- Missani (Omani variety)
4- Cooley (Omani variety)
B)Fertilizer treatments (mineral and organic fertilization):

1. $100 \% \mathrm{~N}$ as mineral fertilizer $(80 \mathrm{~kg} \mathrm{~N}$ fed $^{-1}$ )

2. $50 \% \mathrm{~N}\left(40 \mathrm{~kg} \mathrm{~N} \mathrm{fed}^{-1}\right)+50 \%$ biochar $\left(2.0\right.$ ton DM fed $\left.{ }^{-1}\right)$

3. $50 \% \mathrm{~N}\left(40 \mathrm{~kg} \mathrm{~N} \mathrm{fed}^{-1}\right)+50 \%$ biogas $\left(2.0\right.$ ton DM fed $\left.{ }^{-1}\right)$

4. $50 \% \mathrm{~N}\left(40 \mathrm{~kg} \mathrm{~N}^{-1} \mathrm{fed}^{-1}\right)+50 \%$ compost $\left(2.0\right.$ ton $\left.\mathrm{DM}_{\text {fed }}{ }^{-1}\right)$

5. $50 \% \mathrm{~N}\left(40 \mathrm{~kg} \mathrm{~N} \mathrm{fed}^{-1}\right)+50 \%$ poultry manure (2.0 ton DM fed $\left.{ }^{-1}\right)$

The recommended mineral fertilizer rate $(100 \%)$ for wheat growth in the region of the experiment was $80 \mathrm{~kg} \mathrm{~N} / \mathrm{fed}$ as nitrogen fertilizer, $15.5 \mathrm{~kg}_{2} \mathrm{O}_{5} / \mathrm{fed}$ as phosphorus fertilizer and $24 \mathrm{~K}_{2} \mathrm{O}$ /fed as potash fertilizer. Nitrogen was added in the form of urea $\left(\begin{array}{lll}46 \% & N\end{array}\right)$. Mineral nitrogen fertilizer was divided and applied on three doses ( $r \cdot, 40$ and $40 \%)$. First dose $(r \cdot \%)$ was directly applied before the sowing irrigation, second dose (40\%) was directly applied before the first irrigation, while the third dose $(40 \%)$ was applied before the second irrigation. However, phosphorus fertilizer was added in the form calcium super phosphate $\left(15.5 \% \quad \mathrm{P}_{2} \mathrm{O}_{5}\right)$ before sowing and during the preparation of the experiment. Also, potassium fertilizer was applied in the form of potassium ssulfate $\left(48 \% \mathrm{~K}_{2} \mathrm{O}\right)$ on two equal doses directly before the first and second irrigations. Organic fertilizers as soil amendments (compost, biochar, biogas and poultry manure) were applied into the soil during preparation process as one dose in depth of $0-15 \mathrm{~cm}$. The analysis of different organic fertilizers is presented in Table (1).

Compost used in this investigation was obtained from the Penta of Agricultural investment company for solid waste recycling at Sadat city, Menoufia, Egypt. Biogas as solid product was obtained from Agricultural Waste Recycling Center, Faculty of Agriculture, Benha University, Moshtohor, Egypt. Poultry Manure was obtained from 
M. F. Seleiman, et al.,

Poultry Production Unit, Faculty of Agriculture, Menoufia University, Egypt. Biochar was obtained from Agricultural Research Centre, Giza, Egypt. Subsamples of different organic soil amendments (i.e. compost, biochar, biogas and poultry manure) were analyzed before starting the experiments in Soils, Water and Environment Research Institute, Agricultural Research Centre, Giza, Egypt.

\section{Experimental location description}

Table 1. Analysis of compost, biochar, biogas and poultry manure fertilizers used in the field experiments.

\begin{tabular}{|c|c|c|c|c|}
\hline $\begin{array}{l}\text { Organic fertilizer } \\
\text { Parameter }\end{array}$ & Biochar & Biogas & Compost & $\begin{array}{l}\text { Poultry } \\
\text { Manure }\end{array}$ \\
\hline Weight $(\mathrm{kg})$ of $\mathrm{m}^{3}$ & $\varepsilon V V$ & 630 & 798 & Аร. \\
\hline Moisture \% & $\bullet$ & 6 & 27 & 19 \\
\hline pH 1-10 & 8.19 & 7.30 & 7.66 & 1.79 \\
\hline $\mathrm{EC} \mathrm{dS} / \mathrm{m}$ & r.rv & 0.88 & 3.80 & 7.94 \\
\hline Total N \% & $\cdot . \wedge \mathrm{V}$ & 1.91 & 0.87 & $1 . \mu 1$ \\
\hline $\mathrm{N}-\mathrm{NH}_{4}$ pmm & 111 & 177 & 27 & $10 Y 5$ \\
\hline $\mathrm{N}-\mathrm{NO}_{3} \mathrm{ppm}$ & 33.0 & 215 & 70 & $r \wedge$ \\
\hline OM \% & rY.. & 49.56 & 25.61 & $1 V_{0}^{\circ}$ \\
\hline OC \% & 11.07 & 28.74 & 14.85 & $1 . .0$ \\
\hline Ash \% & 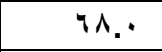 & 50.44 & 74.39 & Ar.o \\
\hline C:N & $r 1: 1$ & $15: 1$ & $17: 1$ & $\mathrm{v}: 1$ \\
\hline Total P \% & $\cdot r$ & 0.73 & 0.79 & $1 . \leqslant V$ \\
\hline Total K \% &.$r^{9}$ & 0.51 & 0.95 &.$r v$ \\
\hline
\end{tabular}

$\mathrm{EC}=$ electrical conductivity; $\mathrm{N}=$ nitrogen; $\mathrm{C}=$ carbon; $\mathrm{OM}=$ organic matter; $\mathrm{OC}=$ organic carbon; $\mathrm{P}=$ phosphorus; $\mathrm{K}=$ potassium.

Table 2. Physical and chemical properties of the experimental soil.

\begin{tabular}{|c|c|c|c|c|c|}
\hline $\begin{array}{l}\text { Season } \\
\text { Parameter }\end{array}$ & 2018/19 & $2019 / 20$ & $\begin{array}{l}\text { Nutrients } \\
\text { (ppm) }\end{array}$ & $2018 / 19$ & $2019 / 20$ \\
\hline Fine sand \% & 23.7 & 24.2 & $\mathbf{N}$ & 51.19 & rI.rr \\
\hline Coarse sand \% & 13.2 & 11.7 & $\mathbf{P}$ & 9.42 & 9.51 \\
\hline Silt \% & 28.7 & 31.0 & $\mathrm{~K}$ & 314.4 & 312.1 \\
\hline Clay \% & 34.4 & 33.1 & $\mathrm{Fe}$ & 3.51 & 3.47 \\
\hline Texture class & \multicolumn{2}{|c|}{ Clay loam } & $\mathrm{Zn}$ & 0.95 & 0.96 \\
\hline pH & 7.34 & 7.51 & Mn & 2.01 & 2.12 \\
\hline E.C. $\mathrm{dS} / \mathrm{m}$ & 0.74 & 0.66 & & & \\
\hline O.M. \% & 1.93 & 1.88 & & & \\
\hline
\end{tabular}


Table 3. Monthly climatic data for the experimental location during first (S1) and second (S2) seasons period in the two growing seasons.

\begin{tabular}{|c|c|c|c|c|c|c|c|c|}
\hline \multirow{3}{*}{ Month } & \multicolumn{4}{|c|}{ Temperature $\left(\mathbf{C}^{0}\right)$} & \multirow{2}{*}{\multicolumn{2}{|c|}{$\begin{array}{l}\text { Precipitation } \\
(\mathrm{mm})\end{array}$}} & \multirow{2}{*}{\multicolumn{2}{|c|}{$\begin{array}{c}\text { Relative } \\
\text { humidity (\%) }\end{array}$}} \\
\hline & \multicolumn{2}{|c|}{ Max } & \multicolumn{2}{|c|}{ Min } & & & & \\
\hline & S1 & S2 & S1 & S2 & S1 & S2 & S1 & S2 \\
\hline November & 26.08 & 28.13 & 14.07 & 14.71 & 7.48 & 0.05 & 57.50 & 53.56 \\
\hline December & 20.15 & 20.97 & 9.85 & 9.77 & 12.19 & 22.25 & 63.91 & 64.01 \\
\hline January & 18.34 & 17.92 & 5.94 & 7.45 & 2.39 & 21.07 & 52.20 & 67.47 \\
\hline February & 20.52 & 20.30 & 7.15 & 8.02 & 5.16 & 26.38 & 54.80 & 64.87 \\
\hline March & 23.36 & 24.41 & 8.95 & 9.74 & 9.59 & 63.01 & 52.56 & 56.91 \\
\hline April & 27.85 & 26.96 & 12.10 & 12.02 & 2.53 & 86.05 & 44.24 & 53.90 \\
\hline May & 36.37 & 32.69 & 17.39 & 15.55 & 0.06 & 0.06 & 30.35 & 47.42 \\
\hline Average & 24.67 & 24.48 & 10.78 & 11.04 & 39.40 & 218.87 & 50.79 & 58.31 \\
\hline
\end{tabular}

\section{Crop management practices}

The area of each sub-plot was $12.0 \mathrm{~m}^{2}$ (4.0 $\mathrm{m}$ long $\times 3 \mathrm{~m}$ width). Also, each subplot consisted of 20 rows with a distance of $15 \mathrm{~cm}$ between each two rows. Sowing date was $16^{\text {th }}$ and $18^{\text {th }}$ November in the first $(2018 / 2019)$ and second $(2019 / 2020)$ seasons, respectively. Grains were manually drilled with seeding rate of 400 grains $/ \mathrm{m}^{2}\left(60 \mathrm{~kg}\right.$ grains fed ${ }^{-1}$ for Egyptian varieties; $50 \mathrm{~kg}_{\text {grains }} \mathrm{fed}^{-1}$ for Omani varieties). Different agricultural practices were performed and done as recommended by Ministry of Agriculture, Egypt for the region of the study. Wide leaves weeds were controlled at 20 days after sowing (DAS) using Gerostar (75\% WC, Methyl 2-\{[(4-methoxy-6-methyl1,3,5-triazinyl) (methyl) carbamoyl] sulfamoyl\} benzoate). While, narrow leaves weeds were controlled at 55 DAS using Axial XL (4.5\% EC). At 110 DAS, Missani variety was suspected to rust diseases that affected wheat plants; therefore, Tilt $(25 \%$ EC) was used to control the rust diseases as foliar application.

Measurements studied:
A- Yield and its components traits:

At harvest, about 145 and 155 days after sowing for Egyptian and Omani varieties, respectively, ten guarded spikes from the main stems were collected in each plot to measure spike characteristics. The middle area in each plot was harvested to estimate the grain and straw yields of wheat, then the values were converted to ton/fed. The following yield and its components characteristics were measured: number of spikes/ $\mathrm{m}^{2}$; number of grains/ spike; 1000-grain weight (g); grain weight / spike (g); grain yield (ton/fed); straw yield (ton/fed).

\section{B-Grain quality traits}

-Grain crude protein (\%): nitrogen content in the whole grains of wheat was analyzed using micro kjeldahl method as described by Peter and Young (1980). The crude protein percentage was obtained by multiplying the nitrogen content in 5.7 according to A.A.C.C. (2010).

-Total carbohydrate percentage: Total carbohydrate percentage in the whole wheat grains was analyzed using the method described by Dubois et al. (1956). 
Statistical analysis:

Different data obtained from the experiments were analyzed using of analysis of variance (ANOVA) according to Snedecor and Cochran (1980). The statistical analysis was done using Costat package program, Version 6.4 (Cohort software, USA). The differences among the means of different the varieties and fertilization treatments were tested using Duncan's multiple range test (Duncan, 1955). The mean values within each column followed by the same letters are not significantly differed at $5 \%$ level of probability.

\section{RESULTS AND DISCUSSION}

\section{Varietal Performances}

The results of yield and its components showed that there are significant differences among the tested varieties as presented in Table (4). The Egyptian varieties, Sakha 95 followed by Gemmeiza 12, surpassed the Omani varieties (Missani and Cooley) in the number of spikes/ $\mathrm{m}^{2}$ (Table 4). For example, Sakha 95 and Gemmeiza 12 varieties had $10.78 \%$ and $6.84 \%$ higher number of spikes/ $\mathrm{m}^{2}$ than Cooley, respectively, as an average of both seasons. The superiority of Sakha 95 and Gemmeiza 12 varieties could be owing to their superiority in the flag leaf area and total chlorophyll content (Data are not presented). In this respect, some researchers found significant variations in the number of spikes/ $\mathrm{m}^{2}$ among different wheat varieties with the superiority for Sakha 94 (Noureldin et al., 2013), Gemmeiza 10 (El-Seidy et al., 2017), Gemmeiza 12 (Seleiman and Abdel-Aal 2018) and Giza 171 (Ibrahim et al., 2019b). Regarding the number of grains/spike, it was a significant variation among the tested four varieties during both seasons (Table 4). In this respect, Sakha 95 and Gemmeiza 12 varieties had the highest values of grains number /spike, while Cooley and Missani varieties had the lowest values. The superiority of the Egyptian varieties in number of grains/spike possibly attributed to the better assimilates as a result of the highest total chlorophyll contents and flag leaf area (Data are not shown) compared to those obtained from Omani varieties. Consequently, such improvement may contribute to the dry matter accumulation of wheat plants and in sequence can increase the number of grains /spike as shown in the current investigation. The number of grains /spike obtained from Sakha 95 and Gemmeiza 12 varieties were higher by 17.27 and $15.54 \%$ than those obtained from Cooley variety, respectively as an average of the two seasons. In this context, other investigators revealed a significant difference among some tested wheat varieties in terms of grains number/ spike in favour of Sakha 93 (Ibrahim et al., 2011), Gemmeiza 12 (Seleiman and Abdel-Aal, 2018) and Gemmeiza 11 (Ibrahim et al., 2019b).

Significant differences were detected among the tested varieties in terms of 1000-grains weight during both seasons as shown in Table (4). Sakha 95 variety followed by Gemmeiza 12 variety had the heaviest 1000-grains weight, while Cooley and Missani had the lowest values of 1000-grains weight. As an average of the two seasons, Sakha 95 and Gemmeiza 12 varieties had heavier 1000-grains weight by 29.40 and $25.28 \%$ than those obtained from Cooley variety, and by 28.04 and $23.96 \%$ than those obtained from Missani variety, respectively. In this context, Asmmawy et al. (2013), Seleiman and Abdel-Aal (2018) and Ibrahim et al. (2019b) revealed differences among wheat varieties in their 1000-grain weight. Also, Al-maskri et al. (2013) reported that 100-grain weight was remarkably high in Cooley variety in comparison to the other six wheat varieties included Missani variety. 
The data presented in Table (4) show that Sakha 95 and Gemmeiza 12 varieties had higher number of grains/spike and 1000-grain weight, subsequently had significantly heavier grain weight/ spike than the other two varieties (Cooley and Missani). The differences among the tested four varieties or between the Egyptian and Omani varieties can be attributed to their morpho- and physiological characteristics and their sink capacity. In this context, some of researchers reported a high variation in grains weight/ spike among different wheat varieties such as Misr 1, Sakha 93, Giza 168 and Gemmeiza 9 (Fayed et al., 2015), Gemmeiza 12, Misr 3, Sakha 95 and Shandaweel 1 (Seleiman and AbdelAal 2018), and Gemmeiza 11, Gemmeiza 12, Misr 1, Giza 171 and Sids 13 (Ibrahim et al., 2019b).

The tested varieties significantly differed in their grain yield/fed in both seasons as reported in Table (4). The highest grain yield /fed was obtained from Gemmeiza 12 (3.165 ton) and Sakha
95 (3.165 ton) varieties without a significant difference between them, while the lowest grain yield was obtained from Cooley (1.464 ton) and Missani (1.589 ton) varieties as average of the two seasons. The superiority of Gemmeiza 12 , Sakha 95 varieties in grain yield/ fed may be attributed to their superiority in number of spikes/ $\mathrm{m}^{2}$, number of grains/ spike, grains weight/ spike and 1000grain weight compared to the other two varieties (Missani and Cooley). In this context, other scholars reported a significant variation among different wheat varieties in their grain yield/ fed in favour of Gemmeiza 10 (Noureldin et al., 2013 and Khafagy, 2016), Gemmeiza 11 (El- Seidy et al, 2017), Misr 2 (Gadallah et al., 2017), Gemmeiza 12 (Seleiman and Abdel-Aal 2018) and Gemmeiza 11 (Ibrahim et al., 2019b). On the other hand, Al-maskri et al. (2013) reported that Missani variety was superior in the grain yield compared to the other six Omani wheat varieties including Cooley variety.

Table 4. Yield, yield components and grain quality of Egyptian and Omani wheat varieties during 2018/2019 and 2019/2020 seasons.

\begin{tabular}{|c|c|c|c|c|c|c|c|c|}
\hline Traits & $\begin{array}{c}\text { No. of } \\
\text { spikes } \\
/ \mathrm{m}^{2}\end{array}$ & $\begin{array}{l}\text { No. of } \\
\text { grains/ } \\
\text { spike }\end{array}$ & $\begin{array}{c}1000- \\
\text { grains } \\
\text { weight }(g)\end{array}$ & $\begin{array}{c}\text { Grain } \\
\text { weight/ } \\
\text { spike (g) }\end{array}$ & $\begin{array}{c}\text { Grain } \\
\text { yield } \\
\text { (ton/fed) }\end{array}$ & $\begin{array}{c}\text { Straw } \\
\text { yield } \\
\text { (ton/fed) }\end{array}$ & $\begin{array}{c}\text { Crude } \\
\text { protein } \\
(\%)\end{array}$ & $\begin{array}{c}\text { Carbohydrates } \\
\text { (\%) }\end{array}$ \\
\hline \multicolumn{9}{|c|}{$2018 / 2019$ season } \\
\hline Gemmiza 12 & $403.0^{a}$ & $58.33^{\mathrm{a}}$ & $46.13^{b}$ & $3.02^{a}$ & $3.186^{a}$ & $3.946^{b}$ & $11.26^{c}$ & $82.67^{a}$ \\
\hline Sakha 95 & $415.6^{a}$ & $59.42^{a}$ & $47.68^{a}$ & $2.96^{b}$ & $3.156^{\mathrm{a}}$ & $3.683^{c}$ & $11.92^{b}$ & $81.95^{b}$ \\
\hline Missani & $393.1^{\mathrm{ab}}$ & $51.15^{\mathrm{b}}$ & $36.94^{c}$ & $2.27^{c}$ & $1.597^{b}$ & $4.297^{a}$ & $15.14^{a}$ & $78.56^{d}$ \\
\hline Cooley & $378.4^{b}$ & $50.37^{b}$ & $36.77^{c}$ & $2.28^{c}$ & $1.464^{c}$ & $4.342^{a}$ & $14.99^{\mathrm{a}}$ & $78.67^{c}$ \\
\hline F. test & * & ** & ** & ** & ** & ** & ** & ** \\
\hline \multicolumn{9}{|c|}{$2019 / 2020$ season } \\
\hline Gemmiza 12 & $399.3^{b}$ & $58.06^{a}$ & $45.74^{b}$ & $2.97^{a}$ & $3.144^{a}$ & $3.880^{b}$ & $11.24^{c}$ & $82.66^{a}$ \\
\hline Sakha 95 & $415.9^{a}$ & $58.70^{a}$ & $47.21^{a}$ & $2.93^{a}$ & $3.105^{a}$ & $3.585^{b}$ & $11.94^{b}$ & $81.91^{b}$ \\
\hline Missani & $383.4^{c}$ & $50.87^{b}$ & $37.17^{c}$ & $2.25^{b}$ & $1.581^{b}$ & $4.249^{a}$ & $15.13^{\mathrm{a}}$ & $78.54^{d}$ \\
\hline Cooley & $372.6^{c}$ & $50.35^{b}$ & $36.55^{d}$ & $2.27^{b}$ & $1.463^{c}$ & $4.333^{a}$ & $15.00^{a}$ & $78.65^{c}$ \\
\hline F. test & ** & ** & ** & ** & ** & ** & $\star \star$ & ** \\
\hline
\end{tabular}

Probability $(P) \geq 0.05=\mathrm{ns} ;{ }^{*}=P \leq 0.05 ;{ }^{* *}=P \leq 0.01$. 
Significant variations were also detected among the tested varieties regarding to the straw yield/fed during both seasons (Table 4). The results showed that Cooley and Missani varieties produced the highest straw yield/fed during both seasons without a significant difference between them. However, Sakha 95 variety had the lowest straw yield/fed followed by Gemmeiza 12 during both seasons (Table 4). It is shown that straw yield/fed of Cooley and Missani varieties exceeded those of Sakha 95 variety by 19.34 and $17.58 \%$ as well as Gemmeiza 12 variety by 9.77 and $9.20 \%$, respectively, as average of the two seasons. The differences in straw yield of tested varieties could be attributed mostly to their plant height in the current study. Varietal differences concerning straw yield/ fed were earlier found by Abdelkhalek et al. (2015), Khafagy (2016), Seleiman and Abdel-Aal (2018) and Ibrahim et al. (2019b).

Data presented in Table (4) show the chemical composition traits (protein and carbohydrate percentages) of the whole meal of grains for the different tested varieties. Significant variations in terms of protein percentage was found among various varieties. The Omani wheat varieties (Missani and Cooley) surpassed Egyptian varieties (Sakha 95 and Gemmeiza 12). For instance, the highest protein content in grains was obtained from Missani variety $(15.14 \%)$, while the lowest protein content was obtained from Gemmeiza $12(11.24 \%)$ as an average of both seasons. This means that protein content obtained from Missani's grains was higher by $34.69 \%$ than that obtained from Gemmeiza 12's grains. Such increments in the protein percentage obtained from Missani and Cooley's grains can be due to lighter of 1000grains weight as reported previously in Table (4).
Significant differences were found also among the evaluated wheat varieties in terms of carbohydrate percentage (Table 4). The Egyptian wheat varieties (Gemmeiza 12 and Sakha 95) surpassed Omani varieties (Missani and Cooley). For instance, the highest carbohydrate content $(82.67 \%)$ in grains was obtained from Gemmeiza 12 variety, while the lowest carbohydrate content (78.54\%) was obtained from Missani as an average of both seasons. Such increments in the carbohydrate percentage obtained from Gemmeiza 12 and Sakha 95's grains can be due to high weight of 1000-grains weight as reported previously compared to the Omani wheat varieties.

\section{Effect of the fertilizations}

Results existing in Table (5) show that the number of spikes/ $\mathrm{m}^{2}$ was significantly varied by the application of different fertilization treatments. The results reveal that the highest significant improvement in the number of spikes $/ \mathrm{m}^{2}$ was achieved by application of $100 \%$ mineral $N$ (F1) followed by the application of $50 \%$ mineral $\mathrm{N}+\mathbf{5 0 \%}$ biogas (F3) compared to other treatments during both seasons. The increments owing to the application of $\mathrm{F1}, \mathrm{F3}$ and $\mathbf{5 0 \%}$ mineral $\mathrm{N}+50 \%$ poultry manure (F5) were higher by 35.11 and $21.86 \%$ and 16.09 , respectively than those obtained from plants fertilized with $50 \%$ mineral $\mathrm{N}+$ $50 \%$ compost (F4) as average of two seasons. The positive effects of the above mentioned treatments of fertilizers on the number of spikes/ $\mathrm{m}^{2}$ may be due to the role of the available nutrients within these treatments, which can improve the flag leaf area and total chlorophyll content. Subsequently, such improve can increase the amount of metabolites synthesized by the wheat plants, which can stimulate the tillers and spikes numbers/ $\mathrm{m}^{2}$. The highest 
improvement that detected when mixture of organic $(50 \%$ biogas) $+50 \%$ mineral $\mathrm{N}$ and $100 \%$ mineral $\mathrm{N}$ treatments might be owing to the availability of nitrogen in soil solution during the early and late tillering stage of wheat plants. In this regard, El-Gizawy (2010) stated that wheat plants fertilized with $80 \mathrm{~kg} \mathrm{~N} /$ fed along with 3 ton/ fed biogas sludge manure significantly produced the highest number of spikes/ $\mathrm{m}^{2}$ compared to lower nitrogen doses. In addition, Ibrahim et al. (2019b) reported that application of $50 \%$ mineral $\mathrm{N} /$ fed $+50 \%$ organic $\mathrm{N} /$ fed resulted in the highest number of spikes/ $\mathbf{m}^{2}$.

Wheat plants fertilized with F1 and F3 treatments exposed increases in number of grains/ spike by 11.18 and $8.49 \%$ in first season and 11.63 and $8.52 \%$ in second season, respectively compared to plants fertilized with F4 treatment (Table 5). These improves as a result of the application of organic and/or mineral fertilizers could be due to their roles in the enhancing total chlorophyll content. The increment in the number of grains per spike can be attributed to the increment in the spike length and the number of spikelets/ spike (Majeed et al., 2014). The positive effects of mineral and organic fertilizers on number of spikelets/ spike or the number of grains/ spike were also coincided with Mandic et al. (2015) and Ibrahim et al. (2019b).

1000-grain weight is considered a function of grain size, shape and density, and is considered an index of potential milling yield. Applications of mineral fertilizers either separately or mixed with organic fertilizations were significantly varied in their effects on 1000- grain weight during both seasons (Table 5). The heaviest 1000- grains weight was obtained from plants fertilized with $100 \%$ mineral $N(F 1)$ and $\mathbf{5 0 \%}$ mineral $N+\mathbf{5 0} \%$ biogas (F3), without a significant difference between them, compared to those obtained from other treatments in both seasons. However, the fertilized plants with $50 \%$ mineral $\mathrm{N}+50 \%$ compost (F4) produced the lightest grain weight in the two seasons. The translocation of photo-assimilate from the vegetative tissues to grains can greatly affected by the status of plant nutrition as reported by Ibrahim et al. (2019b), which can promote cells division and build-up of storage capacity. Moreover, other researchers found that the 1000-grain weight was increased in wheat plants fertilized with $50 \%$ of recommended dose of mineral fertilizers $(\mathrm{NPK})+20 \mathrm{~m}^{3} /$ fed farmyard manure (Attia and Abd El Salam, 2016), or with $50 \%$ mineral $\mathrm{N}+\mathbf{5 0} \%$ organic $\mathrm{N} /$ fed (Ibrahim et al., 2019b).

The data in Table (5) showed that wheat plants fertilized with $100 \%$ mineral $N$ (F1) and $50 \%$ mineral $N+50 \%$ biogas (F3) treatments were the greatest effective treatments in terms of improving grain weight/ spike without a significant difference between both of them during the two seasons. The increment of grain weight/ spike can be associated with the roles of fertilizers in increasing the number of grains/ spike and 1000 -grain weight as shown in the current study. In this context, Noureldin et al. (2013), Mandic et al. (2015) and Ibrahim et al. (2019b) reported that grains weight/ spike was significantly enhanced by different applications of fertilizers. The compost and biochar applications results in the lowest values of grain weight/ spike compared to other treatments, this could be due to the non-significant effect of such organic amendment (biochar) on soil $\mathrm{pH}$, dissolved organic $\mathrm{C}$ and $\mathrm{N}$, ammonium, nitrate or microbial biomass $\mathrm{N}$ (Olmo et al., 2014). 
M. F. Seleiman, et al.,

Table 5. Main effects of different fertilization treatments on yield, yield components and grain quality of wheat plants during $2018 / 2019$ and $2019 / 2020$ seasons.

\begin{tabular}{|c|c|c|c|c|c|c|c|c|}
\hline Treatments & $\begin{array}{l}\text { No. of } \\
\text { spikes/ } \\
\mathrm{m}^{2}\end{array}$ & $\begin{array}{c}\text { No. of } \\
\text { grains/ } \\
\text { spike }\end{array}$ & $\begin{array}{c}1000- \\
\text { grains } \\
\text { weight } \\
\text { (g) }\end{array}$ & $\begin{array}{c}\text { Grain } \\
\text { weight/ } \\
\text { spike } \\
\text { (g) }\end{array}$ & $\begin{array}{c}\text { Grain } \\
\text { yield } \\
\text { (ton/fed) }\end{array}$ & $\begin{array}{c}\text { Straw } \\
\text { yield } \\
\text { (ton/fed) }\end{array}$ & $\begin{array}{l}\text { Crude } \\
\text { protein } \\
(\%)\end{array}$ & $\begin{array}{c}\text { Carbohydrates } \\
(\%)\end{array}$ \\
\hline & & \multicolumn{7}{|c|}{$2018 / 2019$ season } \\
\hline $\mathbf{F 1}$ & $457.6^{a}$ & $57.86^{a}$ & $43.52^{a}$ & $2.76^{a}$ & $2.560^{\mathrm{a}}$ & $4.348^{a}$ & $13.68^{a}$ & $80.07^{d}$ \\
\hline F2 & $378.9^{d}$ & $52.66^{b}$ & $40.64^{c}$ & $2.55^{\mathrm{c}}$ & $2.168^{c}$ & $3.895^{b}$ & $13.70^{\mathrm{a}}$ & $80.04^{d}$ \\
\hline F3 & $414.5^{b}$ & $56.46^{a}$ & $43.44^{a}$ & $2.79^{\mathrm{a}}$ & $2.541^{a}$ & $4.148^{a}$ & $13.05^{b}$ & $80.75^{b}$ \\
\hline F4 & $340.4^{e}$ & $52.04^{b}$ & $40.13^{c}$ & $2.45^{d}$ & $2.065^{d}$ & $3.788^{b}$ & $12.67^{b}$ & $81.15^{a}$ \\
\hline F5 & $396.2^{c}$ & $55.06^{\mathrm{ab}}$ & $41.68^{b}$ & $2.62^{\mathrm{b}}$ & $2.420^{b}$ & $4.156^{\mathrm{a}}$ & $13.52^{a}$ & $80.28^{c}$ \\
\hline \multirow[t]{2}{*}{ F. test } & ** & * & ** & ** & ** & ** & * & ** \\
\hline & & \multicolumn{7}{|c|}{$2019 / 2020$ season } \\
\hline F1 & $457.1^{a}$ & $57.65^{\mathrm{a}}$ & $43.32^{a}$ & $2.74^{\mathrm{a}}$ & $2.545^{a}$ & $4.269^{a}$ & $13.69^{a}$ & $80.06^{d}$ \\
\hline F2 & $369.8^{d}$ & $52.34^{b}$ & $40.30^{c}$ & $2.53^{\mathrm{C}}$ & $2.137^{c}$ & $3.858^{b}$ & $13.71^{\mathrm{a}}$ & $80.03^{d}$ \\
\hline F3 & $410.5^{b}$ & $56.04^{a}$ & $43.04^{a}$ & $2.73^{a}$ & $2.520^{\mathrm{a}}$ & $4.116^{a}$ & $13.02^{b}$ & $80.78^{b}$ \\
\hline F4 & $336.6^{e}$ & $51.64^{\mathrm{bc}}$ & $40.34^{c}$ & $2.42^{d}$ & $2.030^{d}$ & $3.728^{b}$ & $12.66^{c}$ & $81.14^{a}$ \\
\hline F5 & $389.8^{c}$ & $54.80^{\mathrm{ab}}$ & $41.33^{b}$ & $2.61^{b}$ & $2.385^{b}$ & $4.088^{a b}$ & $13.55^{\mathrm{a}}$ & $80.24^{c}$ \\
\hline F. test & ** & * & $* *$ & $* \star$ & ${ }^{* *}$ & * & * & ** \\
\hline
\end{tabular}

$\mathrm{F} 1=\mathbf{1 0 0} \%$ mineral $\mathrm{N}$ fertilizer; $\mathrm{F} 2=\mathbf{5 0} \%$ mineral $\mathrm{N}+\mathbf{5 0} \%$ biochar; $\mathrm{F} 3=\mathbf{5 0} \%$ mineral $\mathrm{N}+\mathbf{5 0} \%$ biogas; $\mathrm{F} 4=\mathbf{5 0} \%$ mineral $\mathrm{N}+\mathbf{5 0} \%$ compost; $\mathrm{F} 5=\mathbf{5 0} \%$ mineral $\mathrm{N}+\mathbf{5 0} \%$ poultry manure. Probability $(P) \geq 0.05=\mathrm{ns} ;{ }^{*}=P \leq 0.05 ;{ }^{*}=P \leq 0.01$.

Grain yield/ fed was varied as a result of the different applications of fertilizers (Table 5). It was obvious that the application of $100 \%$ mineral $N$ (F1) followed by $50 \%$ mineral $\mathrm{N}+50 \%$ biogas (F3) significantly increased grain yield/ fed by 24.67 and $23.59 \%$ compared to plants fertilized with $50 \%$ mineral $\mathbf{N}+$ $50 \%$ compost (F4), respectively as average of the two seasons. However, $50 \%$ mineral $N+50 \%$ poultry manure (F5) and $50 \%$ mineral $N+50 \%$ biochar (F2) treatments ranked as third and fourth in this respect. Thus, the sustainable use of such organic soil amendments is considered very important. The increments in grain yield/ fed as a result of organic fertilizers application could be due to the increments in number of spikes/ $\mathrm{m}^{2}$ and grain weight/ spike. The optimal responses of grain yield/ fed into the application of $100 \%$ mineral $\mathrm{N}$ and /or $\mathbf{5 0} \%$ mineral $\mathrm{N}$ mixed with $\mathbf{5 0 \%}$ organic (biogas or poultry manure) fertilizers indicated that the nutrients availability in the soil (Table 2) were enough to provide the required nutrients of wheat plants. The advantageous effects of biogas or poultry manure applications can be linked with the low level of nutrients leaching and the improvement of nutrients uptake as well as biological activities. In additions, the improvement in the grain yield can be due to the improvement of the soil fertility and available $N$ and $P$ in soil under organic fertilization in a combination with mineral fertilizer compared with the individual 
application of organic or mineral fertilizers (Mahmoud et al. 2019). Moreover, the improvement in grain yield as a result of biogas in combination with mineral fertilizer could be due to the high content of $\mathrm{N}-\mathrm{NO}^{3-}$ (215 ppm) compared to compost (70 ppm), biochar (33 ppm) and poultry manure (28 ppm), (see Table 1). A recent investigation showed that $\mathrm{NO}^{3-}$ based fertilization was superior to ammonium fertilizers (Dier et al., 2018) In this regard, other investigators reported that wheat grain yield was improved with the application of $50 \%$ mineral $\mathrm{N}+50 \%$ poultry manure (Al-Amin et al., 2017), and $75 \mathrm{~kg}$ mineral $\mathrm{N}$ (Noureldin et al., 2013 and El-Seidy et al., 2017). On the contrary, Antoun et al. (2010) reported that the application of $100 \mathrm{~kg} \mathrm{~N}+5$ ton compost/ fed resulted in better wheat grain yield than other fertilization treatments.

Regarding straw yield/ fed, the results indicated that the values were varied under different fertilization treatments (Table 5). The plants fertilized with $100 \%$ mineral $N(F 1), 50 \%$ mineral $N+50 \%$ biogas (F3) and $50 \% N+50 \%$ poultry manure (F5) produced higher straw yield than those obtained from plants fertilized with $50 \%$ mineral $\mathrm{N}+\mathbf{5 0} \%$ compost (F4) or $50 \%$ mineral $N+50 \%$ biochar (F2). For instance, the application of F1, F3 and F5 treatments increased straw yield by 14.63, 9.95 and $9.68 \%$ more than F4 treatment, and by $11.14,6.60$, and $6.34 \%$ more than F2 treatment, respectively as average of the two seasons. The positive effects of investigated and applied fertilizer treatments on straw yield of wheat crop might be attributed to the increments in the number of spikes $/ \mathrm{m}^{2}$ as well as plant height. The results obtained in the current study are in agreement with those achieved by Antoun et al. (2010), Harvey (2017) and Ibrahim et al. (2019b).

Data in Table (5) exhibited that the effects of fertilization treatments on chemical composition of whole meal (protein, carbohydrates percentages). Wheat is considered one of the most important cereal crops with a high demand for nitrogen fertilization to accumulate the grain protein which is necessary for baking and quality control processes (Zörb et al., 2018). Concerning protein \%, it was observed that the application of $100 \%$ mineral $N(F 1), 50 \%$ mineral $N+50 \%$ biogas (F3) and $50 \%$ mineral $\mathbf{N}+50 \%$ poultry manure (F4) were the most effective treatments for increasing protein percentage, while wheat plants fertilized with $50 \%$ mineral $N$ + 50\% compost (F4) had the lowest protein content. For instance, the application of $50 \%$ mineral $N+50 \%$ biochar (F2) resulted in an increment by $8.21 \%$ compared to plants fertilized with F4 treatment as an average of the two seasons. The adequate nitrogen in the rhizosphere zones can enhance the absorption of nitrogen by plant's roots, and this can be a main factor for the increment of the protein percentage. The significant effect of nitrogen on protein percentage could be due its role as an essential element for amino acids molecules; and consequently it plays an essential role in the protein synthesis. Youssef et al. (2013) found the mineral NPK and organic fertilizers (potassium humate or compost tea) resulted in the highest values of protein content in grains compared to plants fertilized with biofertilizer or its combinations with NPK or organic fertilizers.

On the contrary, the application of $50 \%$ mineral $N+50 \%$ compost (F4) resulted in the highest significant carbohydrates percentage (81.15\%) compared to other treatments. The superiority of F4 treatment concerning the increment of carbohydrate can be due to the higher $K$ content in compost compared to other organic fertilizations as shown in Table (1). The application of $50 \%$ mineral $\mathrm{N}+\mathbf{5 0} \%$ compost might enhanced the plants to uptake higher content of potassium into their leaves, 
since $\mathrm{K}$ element plays an important in the translocation of sugars from the leaves to the reproductive organs (grains). The results obtained from the current investigation were in accordance with those revealed by EL- Guibali (2016).

\section{Interaction effects of varieties and fertilizations}

Data (Figure 1) showed that Gemmeiza 12, Missani and Sakha 95 varieties produced the highest number of spikes/ $\mathrm{m}^{2}$ (476.5, 472.0 and 470.6) during first season, and (472.8, 460.0 and 484.0) during second season, respectively when the plants were fertilized with the $100 \%$ mineral $N$ (F1) compared to other treatments. Gemmeiza 12 plants fertilized with $50 \%$ mineral $\mathrm{N}+\mathbf{5 0} \%$ biogas $\mathrm{N} / \mathrm{fed}$ (F3) was the second rank after the above mentioned treatments in terms of number of spikes $/ \mathrm{m}^{2}$ during first (429.1) and second seasons (426.3). However, it was observable that Cooley varieties fertilized with $50 \%$ mineral $\mathrm{N}+\mathbf{5 0} \%$ compost $\mathrm{N} / \mathrm{fed}$ (F4) revealed the lowest numbers of spikes $/ \mathrm{m}^{2}$ (312.6 and 298.1) during the first season and second seasons, respectively compared with other treatments of varieties and nitrogen fertilizations.
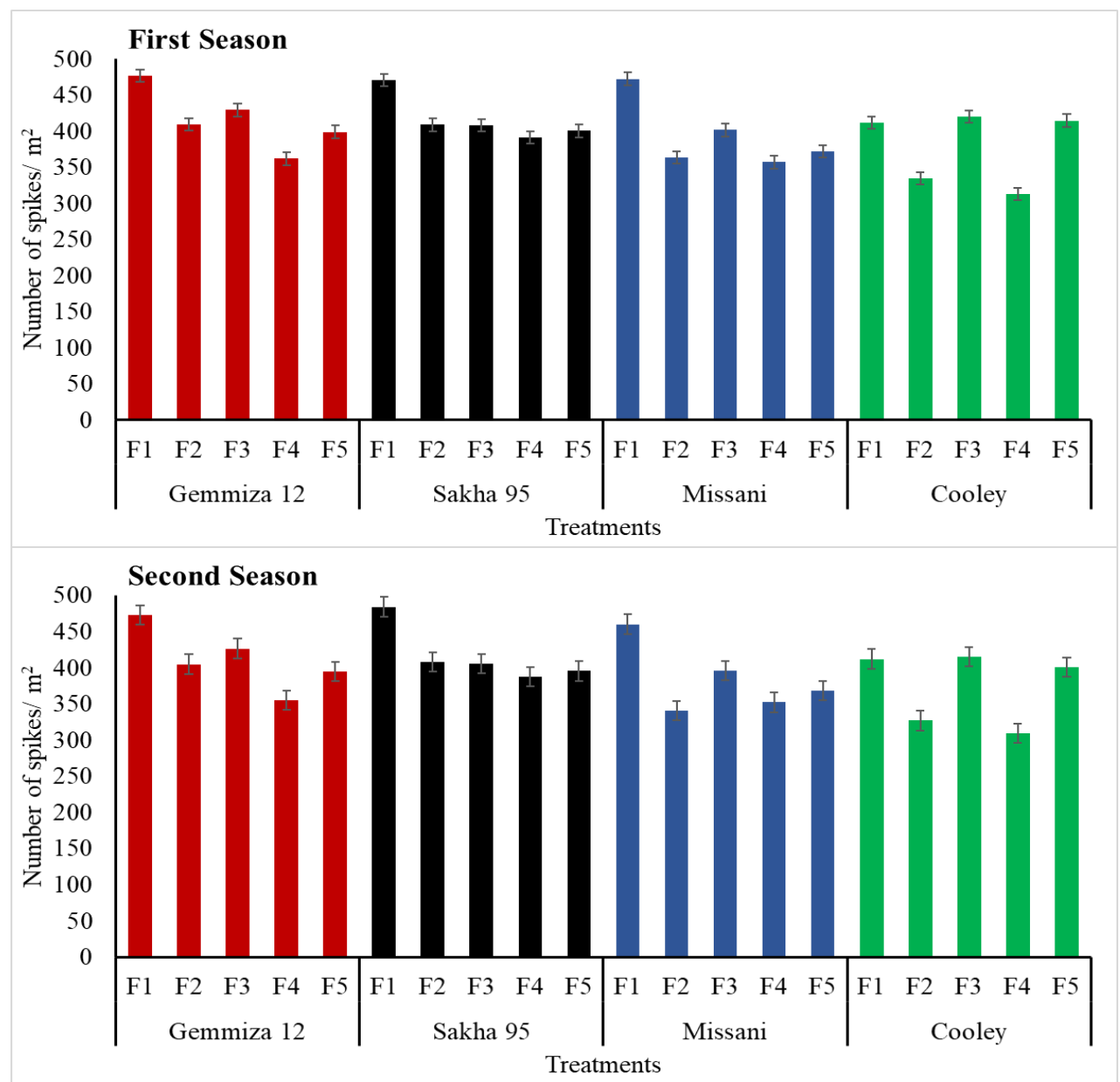

Figure 1. Interaction effects of wheat varieties and fertilization treatments on number of spikes $/ \mathrm{m}^{2}$ during the two seasons. F1 $=100 \%$ mineral $\mathrm{N}$ fertilizer; $\mathrm{F} 2=50 \%$ mineral $N+50 \%$ biochar; $F 3=50 \%$ mineral $N+50 \%$ biogas; $F 4=50 \%$ mineral $N$ $+50 \%$ compost; $F 5=50 \%$ mineral $N+50 \%$ poultry manure. Bars are standard error of means (SEM). 
Regarding number grains/ spike, significant variations were documented among the tested varieties and nitrogen fertilization treatments during both seasons (Figure 2). Gemmeiza 12 and Sakha 95 varieties were the greatest ones in terms of number of grains/ spike when fertilized with $100 \%$ mineral $N(F 1)$ and $50 \%$ mineral $N+50 \%$ biogas (F3), while the lowest values of this trait were obtained from Missani and Cooley varieties when fertilized with $\mathbf{5 0} \%$ mineral $\mathrm{N}+\mathbf{5 0} \%$ compost (F4) or $\mathbf{5 0 \%}$ mineral $\mathrm{N}+$ $50 \%$ biochar (F2). For example, the number of grains/spike was increased by
27.29 and $26.37 \%$ in first season and by 26.69 and $24.79 \%$ in second season when Gemmeiza 12 variety was fertilized with F1 and F3 treatments compared with those obtained from Cooley fertilized with F2 treatment. The superiority of Gemmeiza 12 or Sakha 95 varieties fertilized with F1, F3 and F5 treatments in the number of grains/ spike could be due to the high level of assimilates which could have contributed to the dry matter accumulation during the growth stages. Consequently, this can increase the number of grains/ spike.
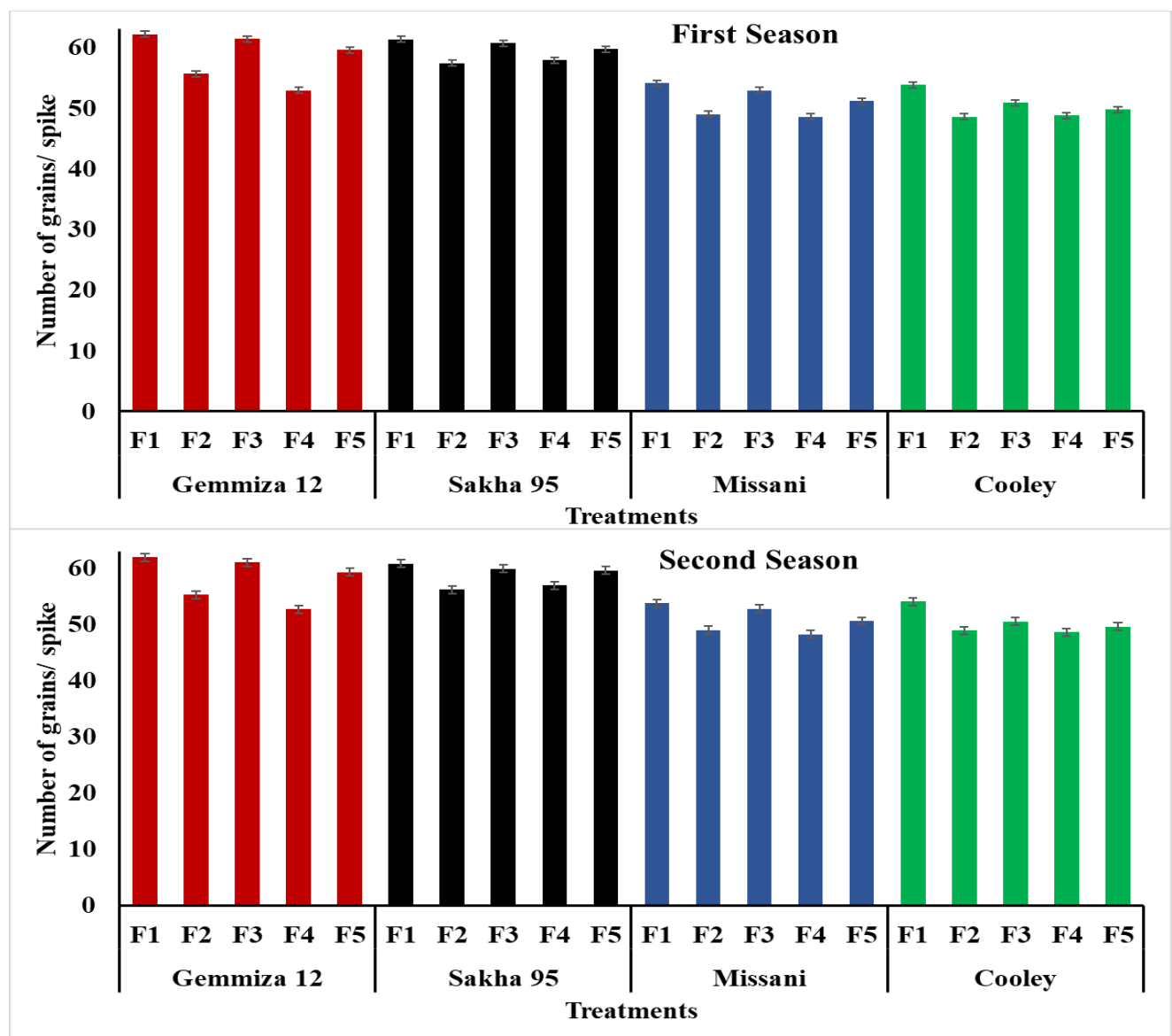

Figure 2. Interaction effects of wheat varieties and fertilization treatments on number of grains/ spike during 2018/2019 (first season) and 2019/2020 seasons (second season). F1, F2, F3, F4 and F5 = See Figure 1. Bars are standard error of means (SEM). 
Concerning the grain weight/spike, Gemmeiza 12 variety fertilized with $\mathbf{5 0 \%}$ mineral $N+50 \%$ biogas (F3) produced the highest grains yield/ spike (3.18 g) followed by Gemmeiza 12 fertilized with $100 \%$ mineral N (F1) and Sakha 95 variety fertilized with $F 1$ and $F 3$ treatments during both seasons compared to other combination treatments (Figure 3). Conversely, Cooley and Missani varieties fertilized with $50 \%$ mineral $\mathrm{N}+\mathbf{5 0} \%$ compost (F4) or $50 \%$ mineral $N+50 \%$ biochar (F2) recorded the lowest grain yield/ spike during first and second seasons. For example, Gemmeiza 12 fertilized with F3 treatment increased grain yield/ spike by $49.64 \%$ compared with Cooley fertilized with F4 treatment as average of both seasons.

In relation to the 1000 -grains weight, it was obvious that there was significant variation among the combinations of different varieties and fertilization treatments (Figure 4). Sakha 95 variety fertilized with $100 \%$ mineral N (F1) or $50 \%$ mineral $N+50 \%$ biogas ( $F 3$ ), followed by Gemmeiza 12 variety fertilized with F1 treatment during both seasons produced the heaviest 1000-grains weight, while Cooley and Missani varieties fertilized with $\mathbf{5 0 \%}$ mineral $\mathrm{N}+\mathbf{5 0} \%$ biochar (F2) or $50 \%$ mineral $\mathrm{N}+50 \%$ compost (F4) produced the lightest 1000-grains weight during both seasons.
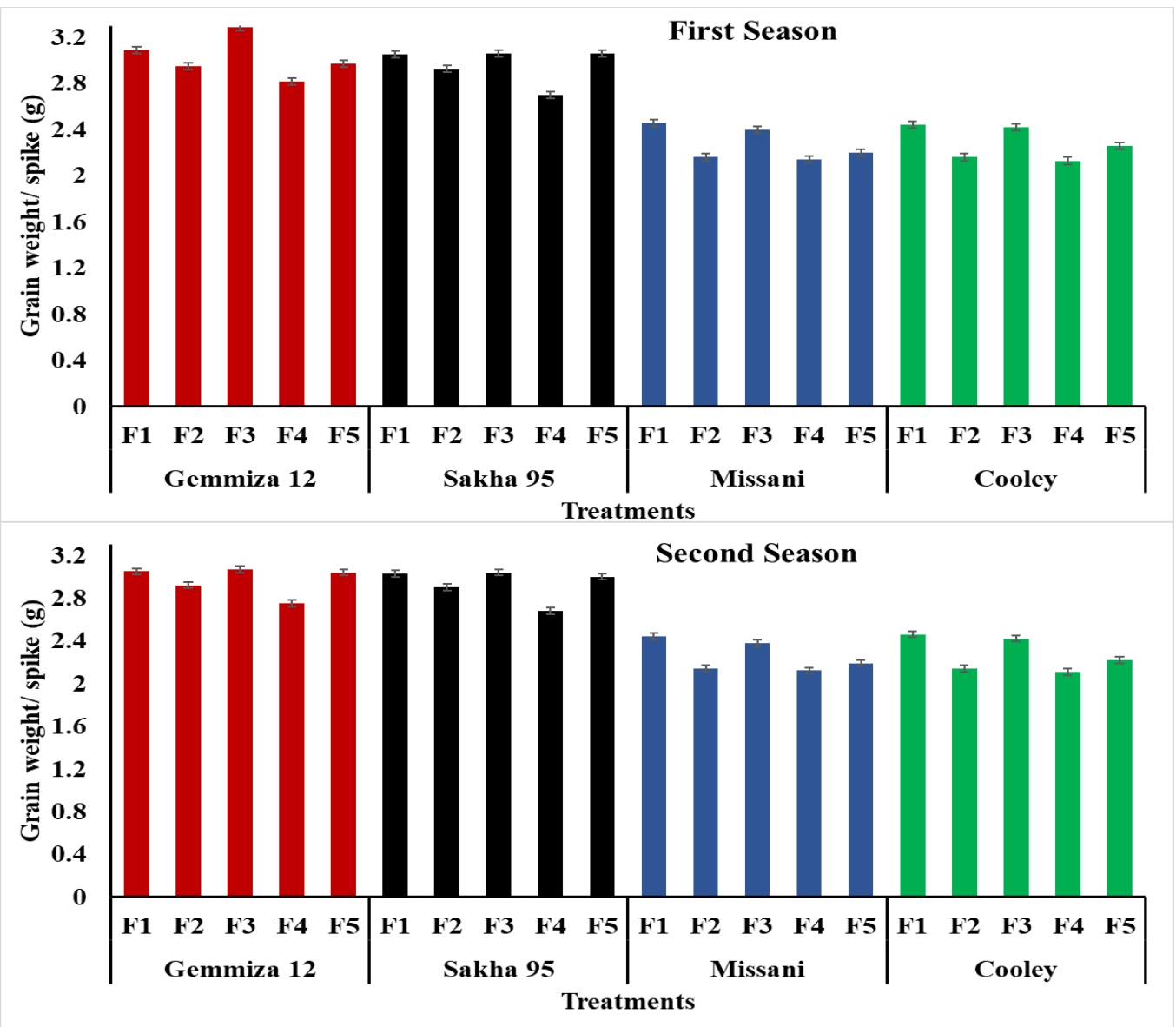

Figure 3. Interaction effects of wheat varieties and fertilization treatments on grain weight/ spike (g) during the two seasons.( F1, F2, F3, F4 and F5 = See Figure 1). Bars are standard error of means (SEM). 

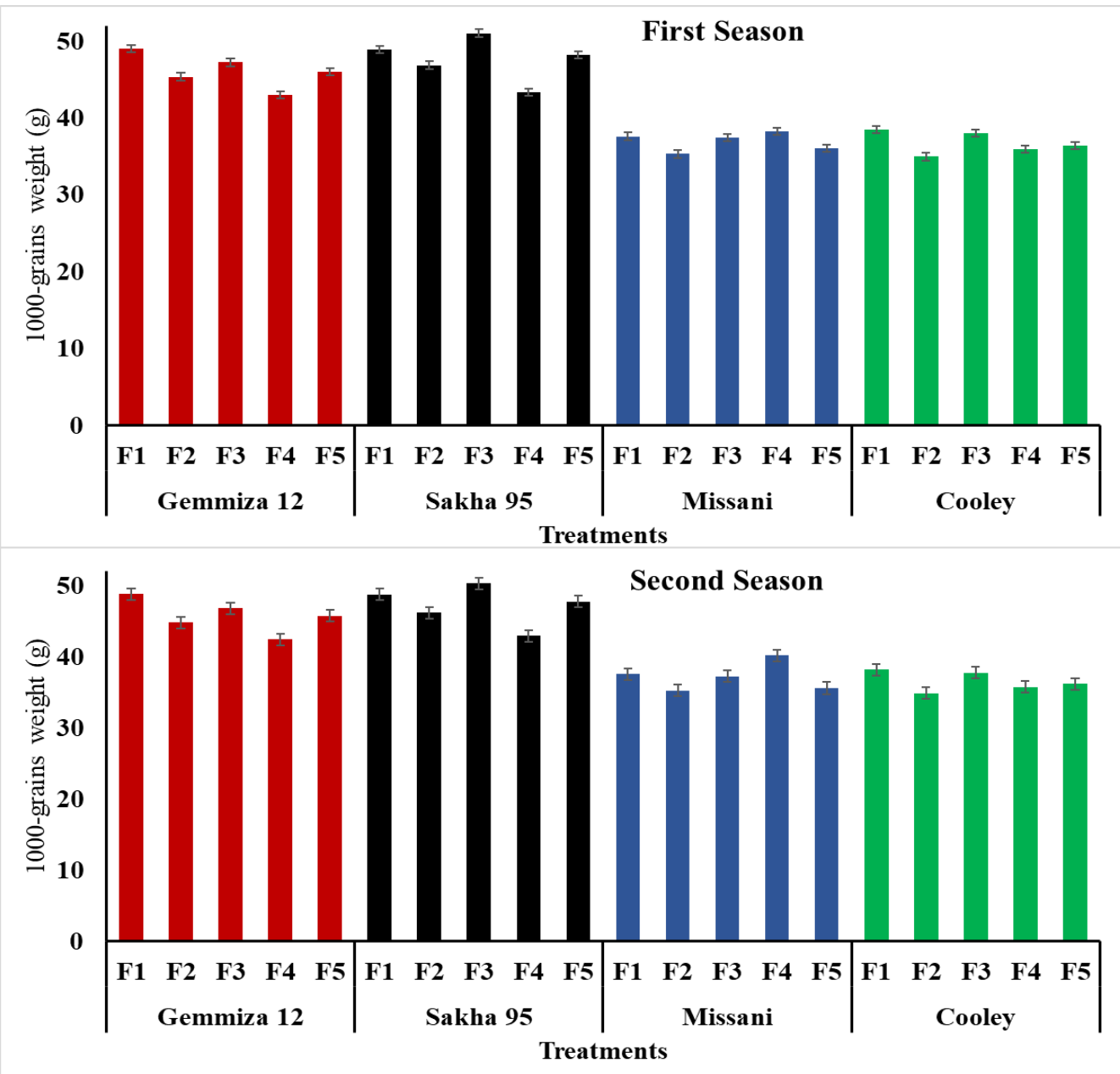

Figure 4. Interaction effects of wheat varieties and fertilization treatments on 1000-grains weight (g) during the two seasons. F1, F2, F3, F4 and F5 = See Figure 1. Bars are standard error of means (SEM).

It is obvious that the tested varieties exhibited different responses to the different treatments of nitrogen fertilizations in terms of grain yield/ fed (Figure 5). The highest grain yield/ fed was obtained from Gemmeiza 12 variety fertilized with $100 \%$ mineral $N(F 1)$, i.e. $3.374 \mathrm{ton} / \mathrm{fed}$, or $50 \%$ mineral $\mathrm{N}+50 \%$ biogas (F3), i.e. $3.353 \mathrm{ton} / \mathrm{fed}$, or Sakha 95 variety fertilized with F1 (3.332 ton/ fed) or F3 treatment (3.304 ton/ fed), while the lowest grain yield/ fed was recorded from Cooley variety fertilized with $50 \%$ mineral $N+50 \%$ biochar (F2), i.e. 1.165 ton/ fed, or $50 \%$ mineral $\mathrm{N}+50 \%$ compost (F4), i.e. 1.162 ton/ fed. This means that Gemmeiza 12 and Sakha 95 varieties fertilized with $F 3$ treatment increased grain yield/ fed by 88.55 and $84.33 \%$ compared with grain yield/ fed obtained from Cooley variety fertilized with F4 treatment as an average of both seasons. 
M. F. Seleiman, et al.,
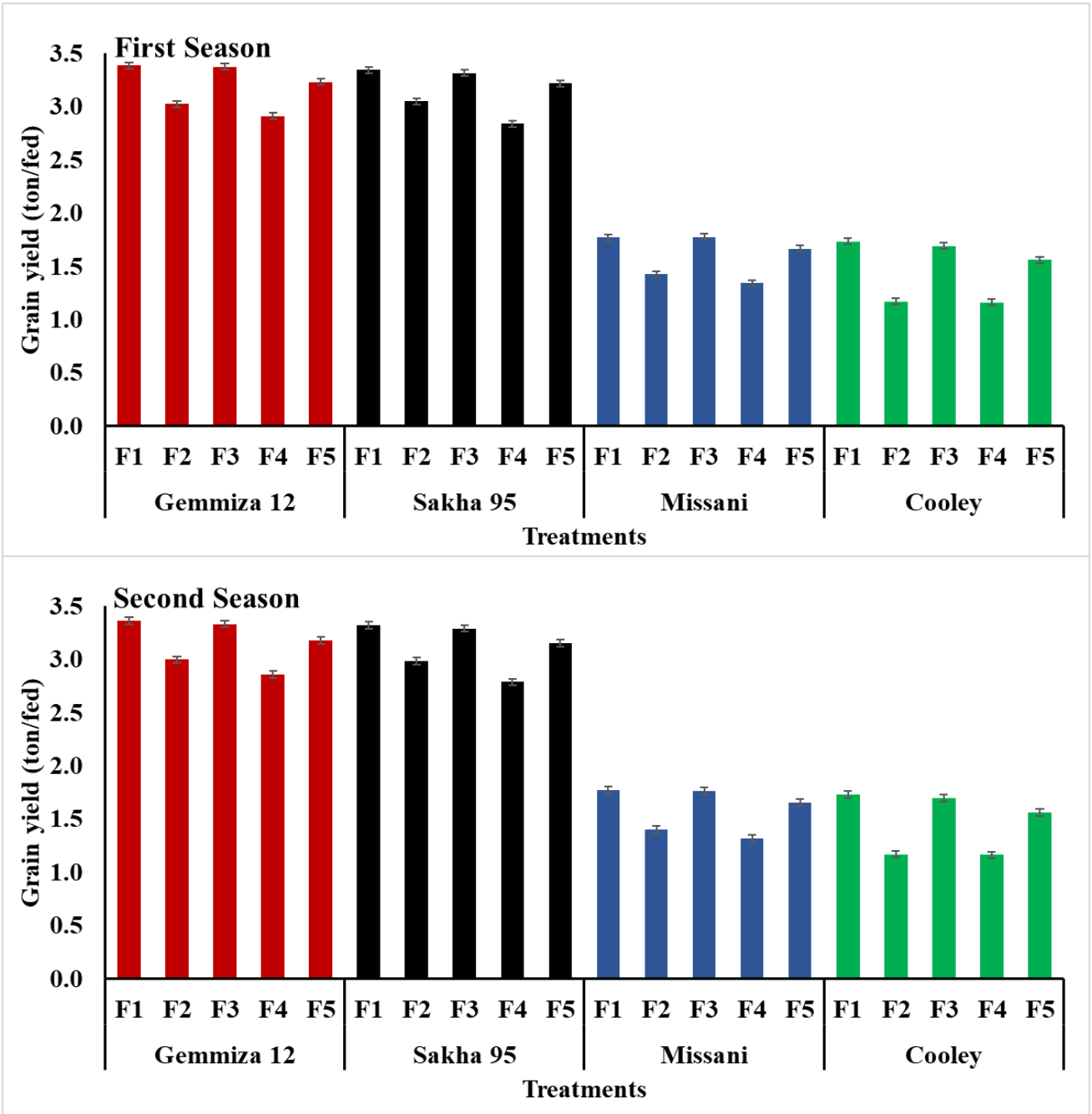

Figure 5. Interaction effects of wheat varieties and fertilization treatments on grain yield (ton/ fed) during the two seasons.( F1, F2, F3, F4 and F5 = See Figure 1). Bars are standard error of means (SEM).

The highest significant straw yield/ fed was obtained from Cooley variety fertilized with $100 \%$ mineral $N(F 1)$, i.e. 4.448 ton/ fed, $50 \%$ mineral $\mathrm{N}+50 \%$ biogas (F4), i.e. 4.502 ton/ fed and $50 \%$ mineral $\mathrm{N}+50 \%$ poultry manure (F5), i.e. $4.489 \mathrm{ton} / \mathrm{fed}$ as well as Missani variety fertilized with F1 treatment (4.451 ton/ fed) and F5 treatment (4.448 ton/ fed) as an average of both seasons compared to other combination treatments (Figure 6). On the other hand, Sakha 95 variety plants fertilized with $50 \%$ mineral $\mathbf{N}+$ $50 \%$ compost $(\mathrm{F} 4)$ had the lowest straw yield/ fed (3.409 ton/ fed) compared to other combinations treatments as an average of the two seasons. 

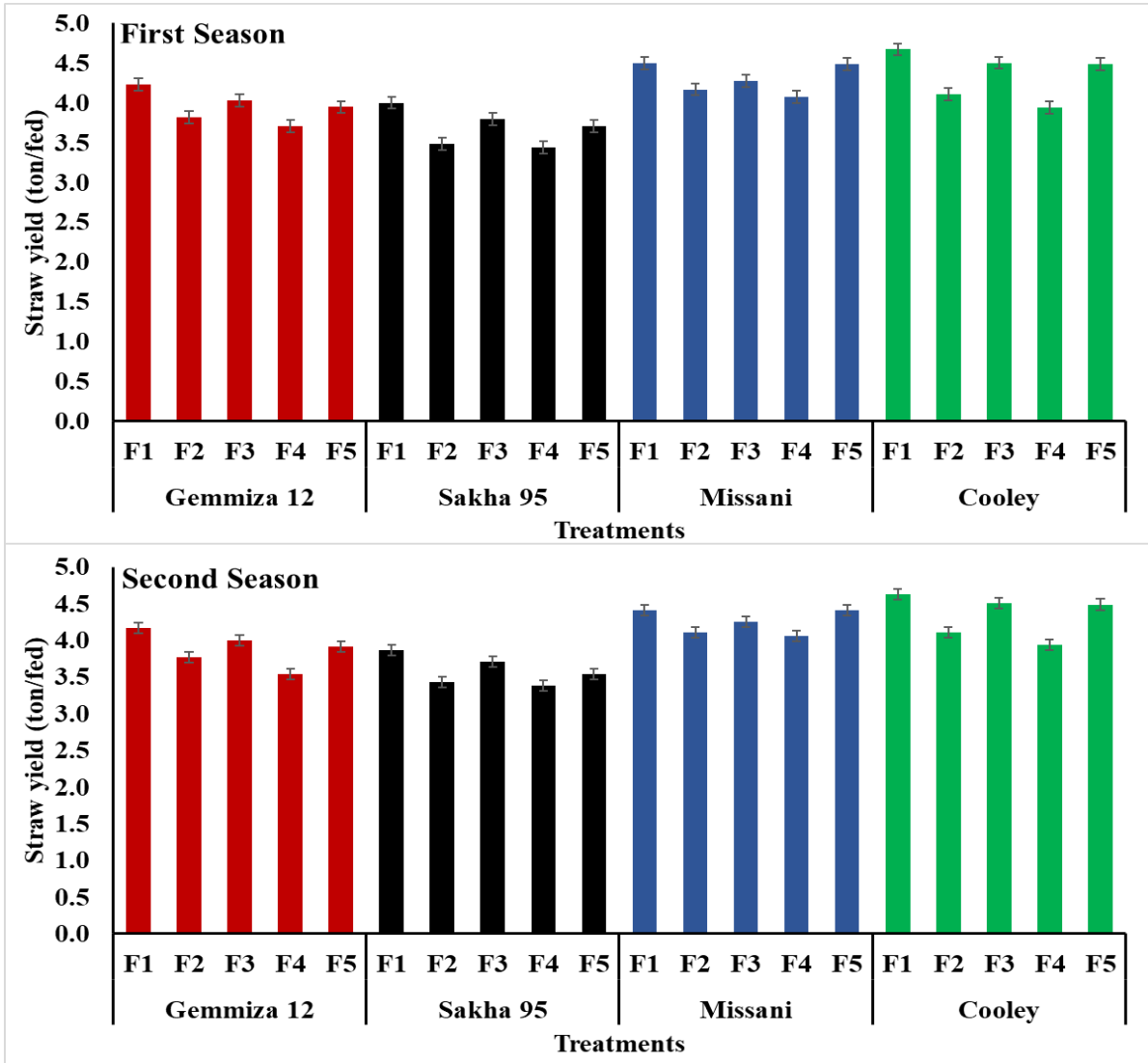

Figure 6. Interaction effects of wheat varieties and fertilization treatments on straw yield (ton/ fed) during the two seasons.( F1, F2, F3, F4 and F5 = See Figure 1). Bars are standard error of means (SEM).

The interactions effects between fertilization treatments and wheat varieties on protein and carbohydrate percentages were found to be significant (Figures 7 and 8 ). It was obvious from Figure (7) that protein \% ranged from 10.35 to $15.82 \%$. The highest protein percentages were obtained from Cooley plants fertilized with $50 \%$ mineral $\mathrm{N}+$ $50 \%$ biochar (F2), $100 \%$ mineral $N$ (F1) and $50 \%$ mineral $N+50 \%$ poultry manure (F5; 15.82, 15.58 and $15.42 \%$, respectively) as well as from Missani plants fertilized with F5, F1 and F3 treatments $(15.57,15.54$ and $15.31 \%$, respectively) without significant differences among them. However, the lowest protein percentages were obtained from Gemmeiza 12 plants fertilized with $50 \%$ mineral $N+50 \%$ compost (F4) and F3 treatments (10.35 and $10.75 \%$ ). The protein percentage obtained from Cooley fertilized with F2 treatment was increased in grains of wheat by $52.85 \%$ compared to that obtained from Gemmeiza 12 plants fertilized with F4 treatment. The effects of interaction between varieties and nitrogen fertilizations on carbohydrates $\%$ were significant as presented in Figure (8). The highest values of carbohydrates $\%$ were obtained from Gemmeiza 12 plants fertilized with $50 \%$ mineral $\mathrm{N}+$ $50 \%$ biogas $(83.13 \%)$ and $50 \%$ mineral $N$ $+50 \%$ compost $(83.61 \%)$, while the lowest value was obtained from Cooley plants fertilized with $50 \%$ mineral $\mathrm{N}$ + $50 \%$ biochar $(77.65 \%)$. 

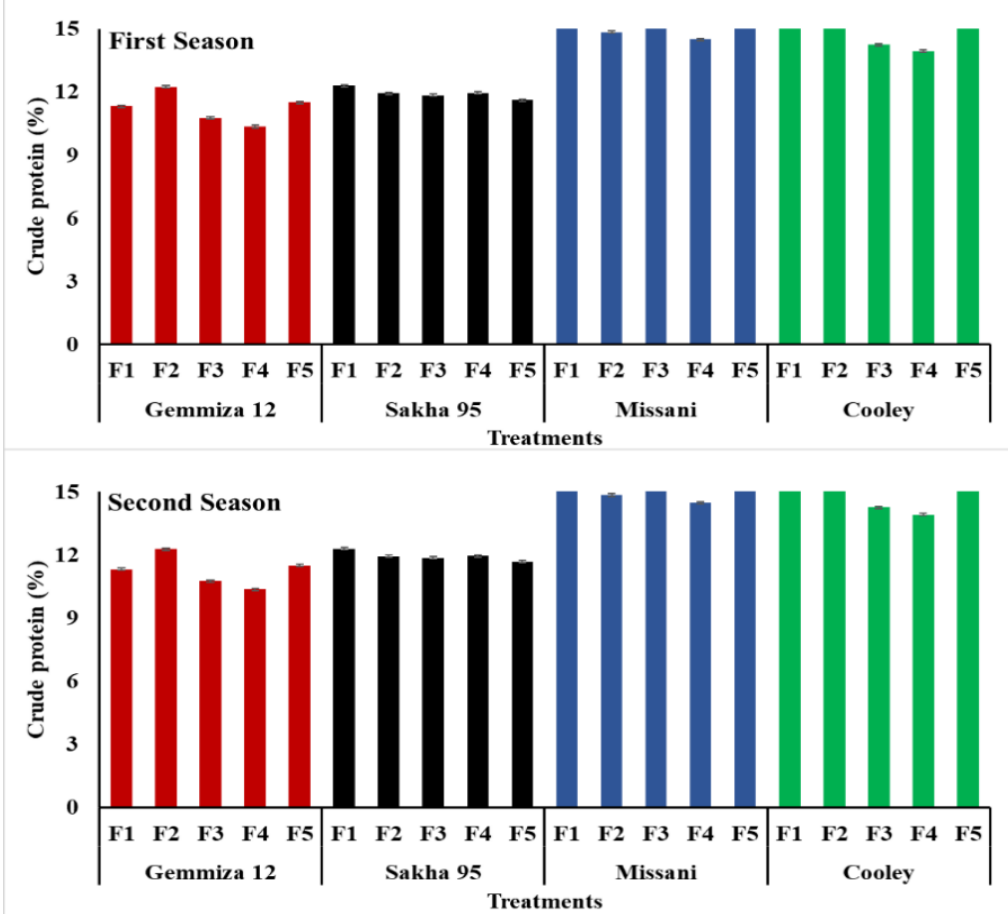

Figure 7. Interaction effects of wheat varieties and fertilization treatments on crude protein (\%) during the two seasons. F1, F2, F3, F4 and F5 = See Figure 1. Bars are standard error of means (SEM).
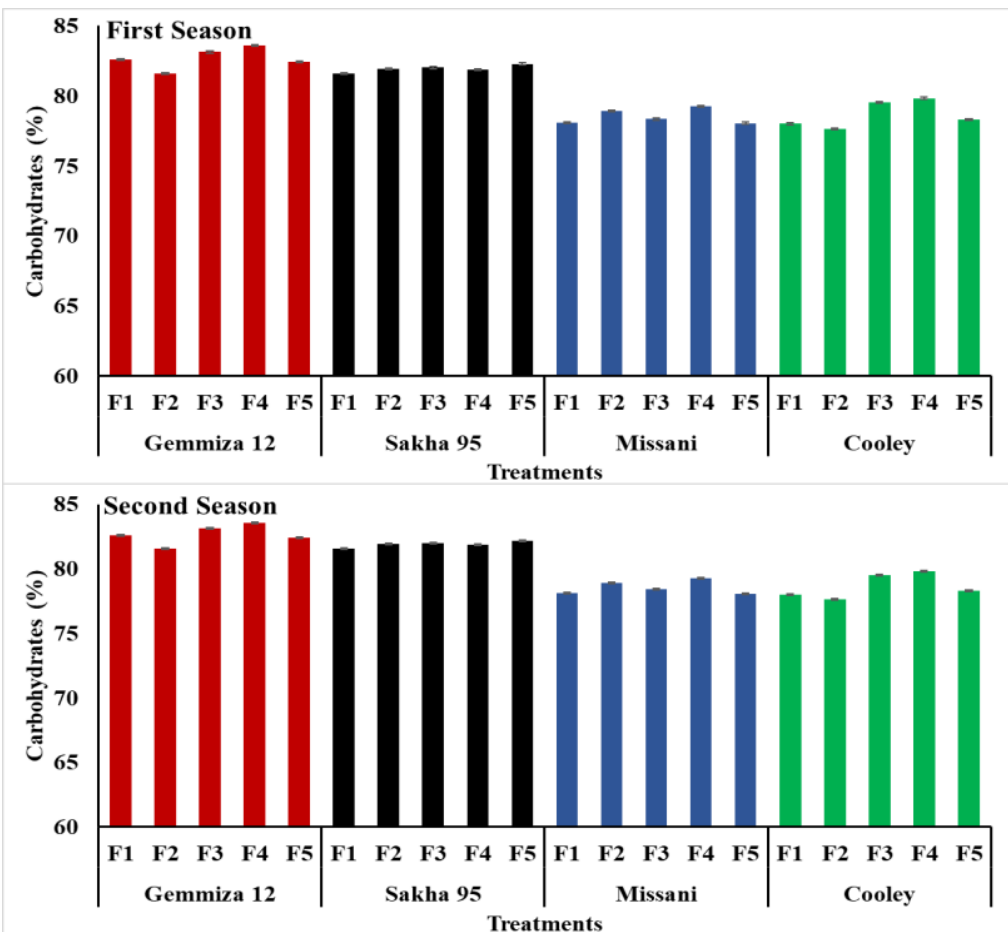

Figure 8. Interaction effects of wheat varieties and fertilization treatments on carbohydrate (\%) during the two seasons. F1, F2, F3, F4 and F5 = See Figure 1. Bars are standard error of means (SEM). 


\section{CONCLUSIONS}

Results in the current investigation showed that response of the tested wheat varieties (Egyptians and Omanis) to different nitrogen fertilization sources was varied. Different organic fertilizers such as biogas or poultry manure should be used as supplementary with mineral fertilizers for improving the wheat productivity and achieve the optimal level of agricultural sustainability. Consequently, a sustainable application of such mentioned organic soil amendments/ fertilizers is a valuable input for agricultural sustainability. Therefore, it is concluded that Egyptian wheat varieties surpassed the Omani varieties in yield and its components as well as carbohydrate percent, while Omani wheat varieties surpassed the Egyptian varieties in straw yield/ fed and protein percent. Also, the application of organic fertilizers resulted in positive improvements in the yield and quality of different tested wheat varieties. New promising wheat varieties can significantly produce higher yield and better quality in the presence of the optimal fertilizer application. Significant increment in the grain yield and grain quality were achieved by varieties when were fertilized with $\mathbf{5 0} \%$ mineral $N+\mathbf{5 0} \%$ biogas or $\mathbf{5 0 \%}$ mineral $\mathrm{N}+\mathbf{5 0} \%$ poultry manure along with $100 \%$ mineral $N$, which were found to be the greatest combined treatments for maximize the grain yield under the environmental conditions of the experimental location.

\section{REFERENCES}

A.A.C.C. (2010). American Association of Cereal Chemists, Approved methods of the American Association of Cereal Chemists $11^{\text {th }}$ ed, St Paul, MN, USA.

Abdelkhalek, A.A., R.K. Darwesh and M.A.M. El-Mansoury (2015). Response of some wheat varieties to irrigation and nitrogen fertilization using ammonia gas in North Nile Delta region. Annals of Agricultural Science 60(2): 245-256.

Abubaker, J., K. Risberg and M. Pell (2012). Biogas residues as fertilisers Effects on wheat growth and soil microbial activities. Applied Energy, 99: 126-134.

Al-Amin, M.A., A.K. Hasan, M.H. Ali, S. Nessa and M.N. Islam (2017). Effect of mulching and organic manure on growth and yield performance of wheat. Archives of Agriculture and Environmental Science 2 (3): 134-140.

Al-maskri, A., M. Hameed and M.M. Khan (2013). Morphological characterization and structural features for high drought tolerance in some Omani wheat landraces. International Conference on Food and Agricultural Sciences, IPCBEE 55 (5): 23-27.

Antoun, Linda W., Sahar M. Zakaria and Hanaa H. Rafla (2010). Influence of compost, N-mineral and humic acid on yield and chemical composition of wheat plants. J. Soil Sci. and Agric. Engi, Mansoura Univ., 1 (11): 1131- 1143.

Asmmawy, M.A., W.M. El-Orabey, M. Nazim and A.A. Shahin (2013). Effect of stem rust infection on grain yield and yield components of some wheat cultivars in Egypt. ESci J. Plant Pathol, 2 (3): 171-178.

Attia, M.A. and A.A. Abd El Salam (2016). Effect of mineral, organic and biofertilizer on yield and yield components of bread wheat at Siwa Oasis. Alex. J. Agric. Sci, 61 (3): 211219.

Dier, M., R. Meinen, M. Erbs, L. Kollhorst, C-K. Baillie, D. Kaufholdt, M. Kücke, H.J. Weigel, C. Zörb, R. Hänsch and R. Manderscheid (2018). Effects of free 
air carbon dioxide enrichment (FACE) on nitrogen assimilation and growth of winter wheat under nitrate and ammonium fertilization. Global Change Biology 24: 40-54.

Dubois, M., K.A. Gilles, J.K. Hamilton, P.A. Robers and F. Smith (1956). Colorimetric method for determination of sugar and related substances. Analytical chemistry, Vol. 28 (3): 350356.

Duncan, D.B. (1955). Multiple range and multiple F. Test. Biometrics, 11: 1-42.

El-Gizawy, N.Kh.B. (2010). Effect of nitrogen, biogas sludge manure and biofertilizer on grain nitrogen uptake and yield of wheat (Triticum aestivum, L.). The international conference of agronomy, 20-22 Sept., 2010, EI Aarish, 1-13.

EL-Guibali, Amal H. (2016). Effect of organic and mineral fertilization on wheat yield and quality. J. Soil Sci. and Agric. Eng., Mansoura Univ., 7 (11): 829- 836.

El-Porai, E.S., A.E. Saiama, A.M. Sharaf, A.I. Hegazy and M.G.E. Gadallah (2013). Effect of different milling processes on Egyptian wheat flour properties and pan bread quality. Annals of Agricultural Science, 58 (1): 51- 59.

El-Seidy, E.H., A. A. Morad, R.A. ElRefaey and Nehal Kh. El-Hadidy (2017). Effect of nitrogen fertilizer levels on some wheat varieties belonging two species. Menoufia J. Plant Prod., 2 (June): 207 - 217.

FAOSTAT (2020). Food and Agriculture Organization of the United Nations Statistics Division. Available online: http://faostat.fao.org/site/567/Desktop Default.aspx.

Fayed, T.B., Eman I. El-Sarag, M.K. Hassanein and A. Magdy (2015). Evaluation and prediction of some wheat cultivars productivity in relation to different sowing dates under North Sinai region conditions. Annals of Agricultural Science, 60 (1): 11-20.

Gadallah, M.A., S.I. Milad, Y.M. Mabrook, A.Y. Abo Yossef and M.A. Gouda (2017). A evaluation of some Egyptian bread wheat (Triticum aesthimaivum) cultivars under salinity stress. Alexandria Science Exchange Journal, 38(1): 259-270.

Harvey, M.M. (2017). Soil physical properties and wheat yield as affected by applying compost and inorganic nitrogen in conventional and no-tillage systems under calcareous soil. Nature and Science, 15 (12): 194-204,

Hlisnikovský, L., L. Menšík and E. Kunzová (2020). The development of winter wheat yield and quality under different fertilizer regimes and soil-climatic conditions in the Czech Republic. Agronomy 10, 1160.

Ibrahim, M., E. Mahmoud, L. Gad and A. Khader (2019a). Effects of biochar and phosphorus fertilizer rates on soil physical properties and wheat yield on clay textured soil in middle Nile Delta of Egypt. Communications in Soil Science and Plant Analysis 50 (21): 2756-2766.

Ibrahim, M.E., A.M.S. Hussein, A.A. Ali and A.H.A. Elkoussy (2019b). Effect of mineral and organic fertilizers on yield and technological traits of some bread wheat varieties. Menoufia Journal of Plant Production 4(1): 19-38.

Ibrahim, M.E., S.M. Abdel-Aal and A.S. Hussein (2011). Technological, rheological and yield differences among Egyptian wheat varieties. J. Sci. Food Agric, 91: 831-840.

Jackson, M.L. (1973). Soil Chemical Analysis. Prentice Hall of India, Ltd., New Delhi, India, 498 p.

Khafagy, E.E.E. (2016). Influence of mineral and organic nitrogen 
fertilizers on growth and yield of some wheat varieties and some soil properties - North Delta. J. Soil Sci. and Agric. Eng., Mansoura Univ., 7 (2): 125-133.

Mahmoud, E., M. Ibrahim, L. Abd ElRahman and A. Khader (2019). Effects of biochar and phosphorus fertilizers on phosphorus fractions, wheat yield and microbial biomass carbon in Vertic Torrifluvents. Communications in Soil Science and Plant Analysis 50 (3): 362-372.

Majeed, M., A. Rashid, T. Muhammad, T. Asif and A. Muhammad (2014). Effect of phosphorus fertilizer sources and rates on growth and yield of wheat (Triticum aestivum L.). Asian Journal of Agriculture and Biology 2:14-20.

Mandic, V., V. Krnjaja, Z. Tomic, Z. Bijelic, A. Simic, D.R. Muslic and M. Gogic (2015). Nitrogen fertilizer influence on wheat yield and use efficiency under different environmental conditions. Chilean Journal of Agricultural Research, 75(1): 92-97.

Noureldin, Nemat A., H.S. Saudy, F. Ashmawy and H.M. Saed (2013). Grain yield response index of bread wheat cultivars as influenced by nitrogen levels. Annals of Agricultural Science, 58 (2): 147-152.

Olmo, M., J.A. Alburquerque, V. Barrón, M.C. del Campillo, A. Gallardo, M. Fuentes and R. Villar (2014). Wheat growth and yield responses to biochar addition under Mediterranean climate conditions. Biology and Fertility of Soils, 50: 1177-1187.
Page, A.L., R.H. Miller and D.R. Keeney (1982). Methods of Soil Analysis. Chemical and Microbiological Properties, $2^{\text {nd }}$ Ed. Amer. Soc. Agron. Inc, Publ. Madison, Wisconsin, USA.

Peter, L.P. and V.R. Young (1980). Nutritional Evaluation of Protein Foods. The United Nations University, Japan, p.8. ( $(0 . v)$

Seleiman, M.F. and M.S.M. Abdel-Aal (2018). Response of growth, productivity and quality of some Egyptian wheat cultivars to different irrigation regimes. Egyptian Journal of Agronomy, 40(3): 313-330.

Seleiman, M.F., S.M. Abdel-Aal, M.E. Ibrahim and P. Monneveux (2010). Variation of yield, milling, technological and rheological characteristics in some Egyptian bread wheat (Triticum aestivum L.) cultivars. Emirates Journal of Food and Agriculture, 22(2): 84-90.

Snedecor. G.W. and W.G. Cochran (1980). Statical Methods $5^{\text {th }}$ lowa State, Univ., Press, lowa, USA.

Youssef, M.A., M.M. EL-Sayed and I.I. Sadek (2013). Impact of Organic Manure, Bio-Fertilizer and Irrigation Intervals on Wheat Growth and Grain Yield. American-Eurasian Journal of Agricultural \& Environmental Sciences, 13 (11): 1488-1496.

Zörb, C., U. Ludewig and M.J. Hawkesford (2018). Perspective on wheat yield and quality with reduced nitrogen supply. Trends in Plant Science 23(11):01029-1037. 


\section{F. Seleiman, et al.,}

تأثير الأسمدة المعدنية والعضوية علي محصول وجودة بعض أصناف القمح المصرية والعمانية

محمود فتحي سليمان ، محمود الاسوقي إبراهيم ، إبراهيم حسيني درويش ،

$$
\text { علي نصيب مبارك حاردان }
$$

قسم المحاصيل - كلية الزراعة - جامعة المنوفية

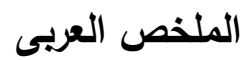

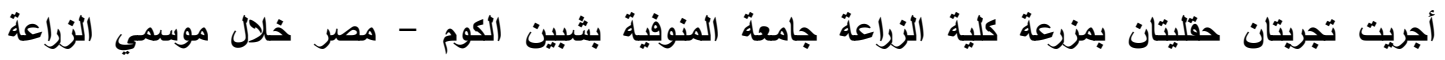

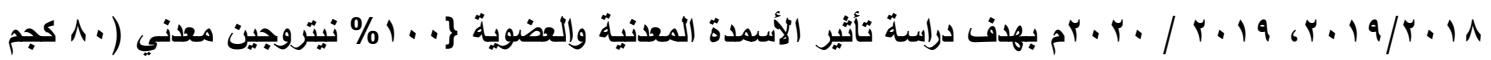

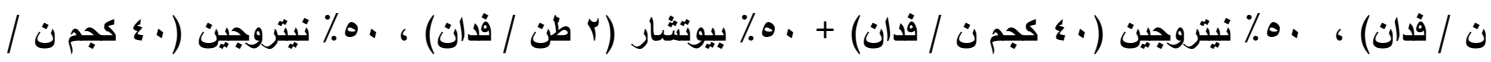

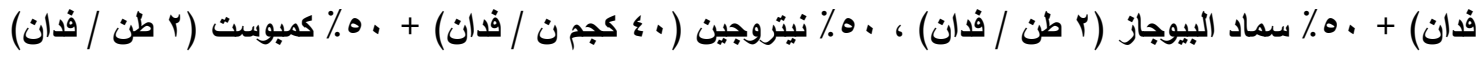

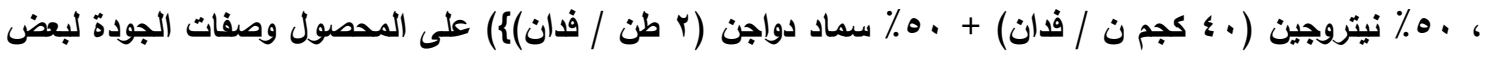

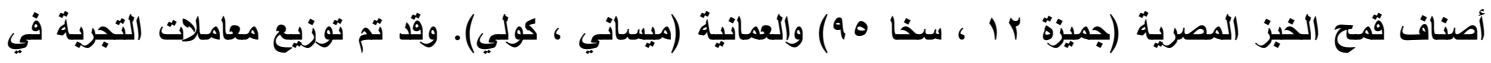

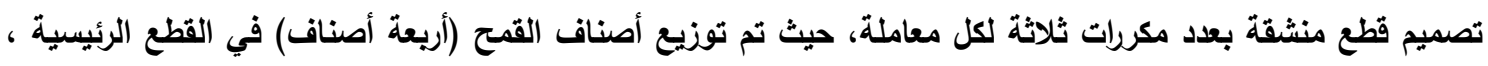

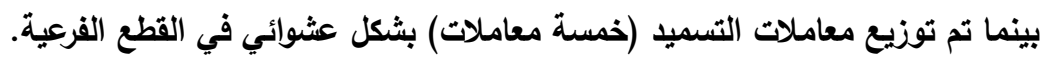

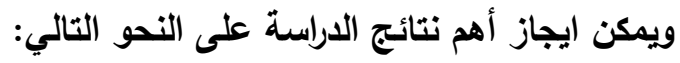
• تفوقت الأصناف المصرية في قيم المحصول ومكوناتة ومحتوي الحبوب من الكربوهيدرات ، بينما تفوقت الأصناف

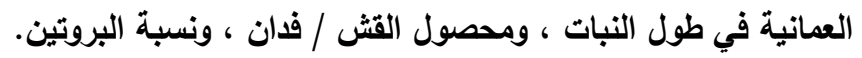

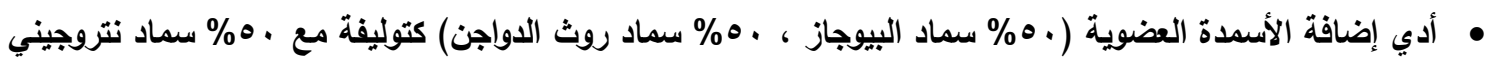
معاني الي زيادة المحصول وتحسين جودة حبوب القمح.

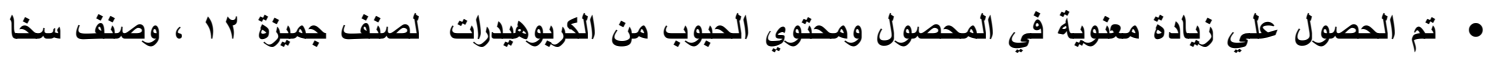

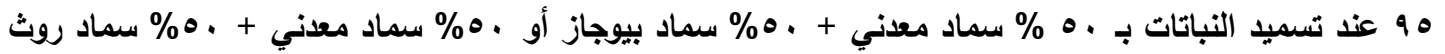
الدواجن كنلك معاملة . . 1 \% سماد معدني حيث تعتبر تلك المعاملات هي الأفضل لتعظيم محصول حبوب القمح تحت

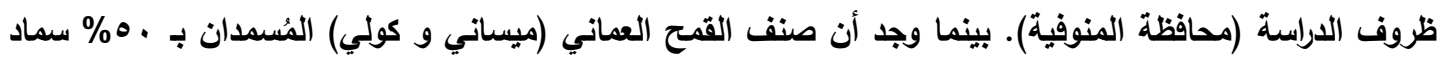

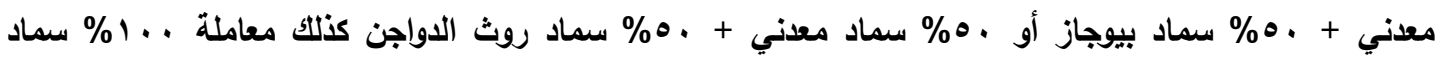

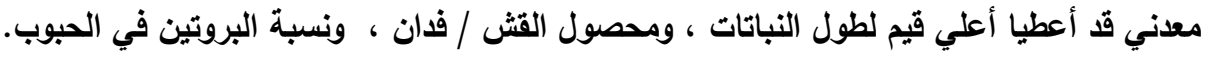

أسماء السادة المحكمين

أ.د/ على عبدالمقصود الحصرى كلية الزراعة بمشتهر - جامعة بنها

أ.د/ سيد محمود عبدالعال كلية الزراعة - جامعة المنوفية 